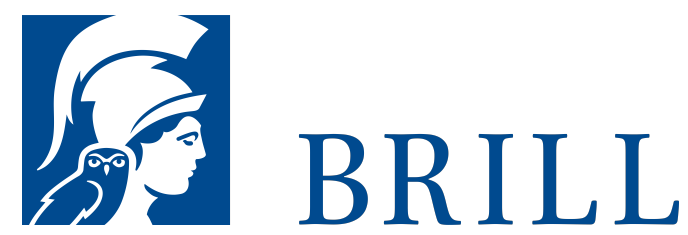

\title{
Operative Chymist
}

\section{Author: Anthony Morson}

T.N.R. Morson was born just as chemistry started to be a science. Trained in Paris, he introduced to Britain quinine and morphine followed by many other medicines. His pioneering achievements were recognised by his medical contemporaries. His contributions to the progress of science and its institutions included work at the Society of Arts and the Royal Institution. He was as well-known in Paris as in London. He was a founder of the Pharmaceutical Society becoming its President in 1848 and 1859 . He created a substantial pharmaceutical chemical business with world-wide interests.

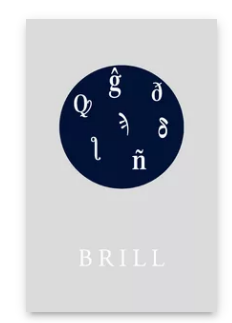

Pages: xii, 294 pp.

Language: English

Subjects:

History of

Medicine,

History

Publisher: Brill

Series:

Clio Medica

Online, Volume:

45

Clio Medica,

Volume: 45

E-Book (PDF)

Released online:

10 Feb 2020

ISBN: 978-90-

04-41854-7

List price

USD \$137.00

Hardback

Publication date:

o1 Jan 1997

ISBN: 978-90-

420-0376-7

List price

USD \$129.00

Paperback

Publication date:

o1 Jan 1997 
For more information see brill.com

ISBN: $978-90-$

420-0366-8

Order information: Order online at brill.com +44330 333 0049 | customerservices@brill.com Submission information: brill.com/authors

Titles published by Brill | Fink, Brill | mentis or Brill | Schöningh: +49(o)715413279216| brill@brocom.de 